\title{
Assessment of Nurses Knowledge Regarding Jaundice in Basra Hospitals
}

\author{
Abdulkareem Salman Khudhair* \\ Department of fundamentals of Nursing, College of Nursing, University of Basra, Basra, Iraq \\ *Corresponding author
}

\section{A B S T R A C T}

A descriptive study was carried out at the Basra Hospitals started from November $2^{\text {th }} 2017$

Keywords

Assessment,

Knowledge

Regarding Jaundice,

Basra Hospitals

Article Info

Accepted:

16 August 2018

Available Online:

10 September 2018 to $2^{\text {th }}$ march, 2018. The study aims to assess nurse's knowledge concerning jaundice, and to identifying the relationship between nurse's knowledge and their demographic characteristic. A purposive sample of (100) nurses was selected on the surgical wards in Basra hospitals (AL-Sader, AL-Basra, AL-Fyhaa, and AL-Mawani). The data were collected through the use of direct interview, which comprised of (30) items as mean of data collection. The data were analyzed through the application of descriptive statistical analysis that includes frequency and percentage, and the application of inferential statistics that including the mean of score, and Chi - square test. The study shows that the majority of the nurses were males $(60 \%)$, with age group (25-29) years old (28\%), nursing institute graduate $(48 \%)$, the majority of nurses have than less $(1-5)$ years of experience $(44 \%)$. The result indicated that there were no significant associations between the nurse's gender, age, years of experience and their knowledge, and there were significant associations between the nurse's level of education and their knowledge. The results demonstrated a knowledge deficit in the most items of questioner about jaundice in all hospitals.

\section{Introduction}

Jundice is a condition in which a person's skin and the whites of the eye are discolored yellow due to an increased level of bile pigments in the blood resulting from liver disease (Lewis et al., 2000; Smeltzer et al., 2010). Yellowness of skin, sclera, mucous membranes, and excretions due to hyperbilirubinemia and deposition of bile pigments (Click et al., 2013). Jaundice is not a disease; it is a symptom of a number of different diseases and disorders of the liver and gallbladder and of hemolytic blood disorders (James et al., 2005). There are many different causes for jaundice, but they can be divided into three categories based on where they start before, in, or after the liver (pre hepatic, hepatic and post hepatic) (Labori et al., 2003; Marshall et al., 1995). The three types of jaundice are classified as hemolytic, hepatocellular, and obstructive (Wheatey and Heilpem, 2008).

Hemolytic (pre hepatic) jaundice is due to an increased break down of red blood cells (RBC) which products an increased amount of unconjugated bilirubin in the blood (Bansal and Schuchert, 2006). A Hepatocellular (hepatic) jaundice result from the liver's 
altered ability to take up bilirubin from the blood or to conjugate or excrete it (Labori and Reader, 2004). Obstructive (post hepatic) jaundice is due to impeded or obstructed flow of bile through the liver or biliary duct system (Whitehead et al., 2001).

The nurses should asses for the degree of jaundice. In light-skinned persons the jaundice is usually observed first in the sclera of the eyes and later in the skin. In dark-skinned persons, jaundice is observed in the hard palate of the mouth and inner canthus of the eyes (Forrest and Forrest, 2002; Yu et al., 2012). The nurse plays an important role in the therapeutic success and outcome of the patient because they educated the patient about the types of jaundice and to prevent complications through maintaining strict aseptic technique (Carol and Taylor, 2008).

Today infection increased the financial cost on the patients, increase the use of antibiotics, increase in the consumption of medical supplies and increase of time consuming for personnel in the health sector (American Academy of Family Physicians, 2014).

\section{Materials and Methods}

The study aims to assess nurse's knowledge concerning jaundice in Basra hospitals and to finding out the relationship between nurse's knowledge and their demographic characteristics, which include (age, gender, level of education, and years of employment).

A descriptive design was conducted on the surgical wards in AL-Sader Teaching Hospital, AL-Basra general Hospital, ALFyhaa general Hospital, and AL-Mawani general Hospital started from November $2^{\text {th }}$ 2017 to $2^{\text {th }}$ march, 2018 in order to assess nursing knowledge concerning jaundice. A probability sample of (100) nurses males and females, who were in the all wards. For the purpose of the study, the researcher constructed the study instrument because no existing tool was found to measure the desired knowledge. The construction was based on the extensive review of relevant literature and related studies. A questionnaire format was used for data collection, which consisted of (2) parts. The overall number of the items included in the questionnaire was (30). The items were rated on three level likertscales: know, uncertain, and don't know and scored as 3,2, and 1, respectively, cutoff point was (2). The first part of the questionnaire sheet included (4) items relative to the demographic data of the nurses who work in all wards and units and included; age, gender, level of education, years of employments. The second part of the questionnaire was comprised (30) items that concerned with nurses knowledge relative to jaundice. Data were collected through direct interview with the nurses of the sample. The data analyze through the use of descriptive statistical (frequency and percentage) and the use of inferential statistical (mean of score and chi-square $\left(X^{2}\right)$. The mean of score, which was equal to (2), was considered significant if greater than (2) and less than (2) was considered nonsignificant. Chi-square $\left(X^{2}\right)$ used to determine the significant relationship between the nurse's knowledge and their demographic characteristics at $\mathrm{p} \leq 0.05$.

Table 1 reveals that the majority of the sample were males (56\%), (20-29) years old (44\%), secondary nursing school (48\%), (1 -9) years of employment $(61 \%)$.

The findings of table 2 indicate that the nurses have adequate knowledge concerning jaundice on items $1,6,12,13 \& 27$ and inadequate on the remaining items.

The finding of this table 1 presented that there were no significant associations between the nurse's gender and their knowledge. 
The finding of this table 1 presented that there were no significant associations between the nurse's age and their knowledge.

The finding of this table 1 presented that there were significant associations between the nurse's level of education and their knowledge. The finding of this table 1 presented that there were no significant associations between the nurse's years of experience and their knowledge.

\section{Results and Discussion}

Throughout the course of the present study, it has noticed that the majority (56\%) of the study sample was males. The highest proportion $(44 \%)$ of them was (20-29) years old. concerning level of education, secondary nursing school (48\%), (1-9) years of employment $(61 \%)$. Throughout the use of observational checklist the highly percentage of nurse's have adequate knowledge in items concerning (1, 6, 12, 13 and 27).
Throughout the use of statistical analysis there were no significant relationships between nurse's knowledge and their age, gender \& years of employment (Table 3, 4 and 6), while they were high significant relationships between nurse's knowledge and their level of education (Table 5). So nurses with low certification and inadequate knowledge cannot do difficulty responsibilities for patients.

The researchers suggest an opportunity for nurses to be enrolled in training sessions to improve their knowledge.

According to the findings of the study and their discussion, the researcher concluded that:

The majority of the study nurse were males (56\%), (20- 29) years old (44\%), nursing institute graduate $(48 \%),\left(\begin{array}{ll}1 & -9\end{array}\right)$ years of employment $(61 \%)$.

The results demonstrated a knowledge deficit in the most items.

Table.1 Distribution of nurses by their demographic data

\begin{tabular}{|l|}
\hline 1. Gender \\
\hline Male \\
\hline Female \\
\hline Total \\
\hline 2. Age $\quad$ A0-29 \\
\hline 30-39 \\
\hline $40-49$ \\
\hline Total \\
\hline $3 . \quad$ Level of education \\
\hline Secondary nursing school \\
\hline Nursing institute graduate \\
\hline Nursing college graduate \\
\hline Total \\
\hline $4 . \quad$ Years of employment \\
\hline $1-$ \\
\hline $10-19$ \\
\hline $20-29$ \\
\hline Total \\
\hline
\end{tabular}

\begin{tabular}{|l|l|}
\hline F & $\%$ \\
\hline 56 & $56 \%$ \\
\hline 44 & $44 \%$ \\
\hline 100 & $100 \%$ \\
\hline 44 & $44 \%$ \\
\hline 25 & $25 \%$ \\
\hline 31 & $31 \%$ \\
\hline 100 & $100 \%$ \\
\hline & \\
\hline 48 & $48 \%$ \\
\hline 35 & $35 \%$ \\
\hline 17 & $17 \%$ \\
\hline 100 & $100 \%$ \\
\hline & \\
\hline 61 & $61 \%$ \\
\hline 22 & $22 \%$ \\
\hline 17 & $17 \%$ \\
\hline 100 & $100 \%$ \\
\hline
\end{tabular}


Table.2 Mean of scores of the nurse's knowledge concerning jaundice

\begin{tabular}{|c|c|c|c|c|c|}
\hline $\mathbf{N}$ & Items & know & $\begin{array}{l}\text { Un } \\
\text { certain }\end{array}$ & $\begin{array}{l}\text { don't } \\
\text { know }\end{array}$ & M.S \\
\hline 1 & $\begin{array}{l}\text { Jaundice is a darkening of the skin and mucous membranes solid (whites of the eyes) in } \\
\text { yellow }\end{array}$ & 35 & 35 & 30 & 2.5 \\
\hline 2 & Three types of jaundice (lytic, obstructive, inflammation) & 20 & 41 & 39 & 1.81 \\
\hline 3 & $\begin{array}{l}\text { The cause of jaundice is high or hypertext accumulation of bilirubin in the blood and } \\
\text { tissues of the body }\end{array}$ & 25 & 44 & 31 & 1.49 \\
\hline 4 & Bilirubin is the sum of waste produced when red blood cells break down & 23 & 32 & 45 & 1.78 \\
\hline 5 & The normal range for bilirubin $0.1-3.0$ melgm $\backslash \mathrm{dl}$ & 18 & 43 & 39 & 1.79 \\
\hline 6 & $\begin{array}{l}\text { Symptoms of jaundice in adults yellow appear on (the skin, whites of the eyes, and under } \\
\text { the tongue) }\end{array}$ & 45 & 25 & 30 & 2.15 \\
\hline 7 & $\begin{array}{l}\text { Symptoms of jaundice in adults is also a sense of apathy and laziness, vomiting, nausea, } \\
\text { itching and sometimes constipation }\end{array}$ & 15 & 40 & 45 & 1.70 \\
\hline 8 & $\begin{array}{l}\text { Symptoms when adults are also an imbalance in the nerves and lack of appetite, pain in } \\
\text { the upper area of the abdomen }\end{array}$ & 14 & 39 & 47 & 1.67 \\
\hline 9 & $\begin{array}{l}\text { Jaundice is threatening complications as serious as hearing loss and the destruction of } \\
\text { brain cells }\end{array}$ & 29 & 33 & 38 & 1.91 \\
\hline 10 & Complications of jaundice sepsis, especially in the bile ducts and liver cirrhosis & 18 & 44 & 38 & 1.80 \\
\hline 11 & Lytic jaundice caused by a broken red blood cells & 20 & 39 & 41 & 1.79 \\
\hline 12 & Jaundice is caused by inflammationary total of viral hepatitis & 42 & 22 & 36 & 2.06 \\
\hline 13 & Obstructive jaundice caused by a blockage of the bile duct (gallstones, and the tumor) & 33 & 38 & 29 & 2.04 \\
\hline 14 & Obstructive jaundice and amplification are the two most common in adults & 21 & 33 & 46 & 1.75 \\
\hline 15 & $\begin{array}{l}\text { Gallbladder cancer, bile duct cancer are relatively rare condition may cause obstructive } \\
\text { jaundice }\end{array}$ & 27 & 26 & 47 & 1.80 \\
\hline 16 & Some drugs can cause jaundice (such as paracetamol...) & 16 & 40 & 44 & 1.72 \\
\hline 17 & The use of alcohol and drugs can cause jaundice inflationary & 20 & 30 & 50 & 1.70 \\
\hline 18 & Spiral disease bacterial infection caused by animals jaundice inflationary & 23 & 33 & 44 & 1.79 \\
\hline 19 & Malaria is transmitted through blood by mosquitoes cause jaundice lytic & 25 & 44 & 31 & 1.94 \\
\hline 20 & $\begin{array}{l}\text { Jaundice may be the result of hereditary condition such as ((thalassemia syndrome } \\
\text { Aljelbrt)) }\end{array}$ & 26 & 34 & 40 & 1.86 \\
\hline 21 & $\begin{array}{l}\text { Symptoms of jaundice in new-borns italic skin yellow, yellowing of the eyes, severe } \\
\text { crying, poor feeding }\end{array}$ & 17 & 37 & 46 & 1.71 \\
\hline 22 & Lytic jaundice is more common in new-borns & 22 & 32 & 46 & 1.76 \\
\hline 23 & $\begin{array}{l}\text { Jaundice occurs in new-borns because of abnormal physiology or where a child is born a } \\
\text { very large number of red blood cells which is not needed by the body and thus cracking } \\
\text { process is happening or to blood cells and excess saw her self-analysis about the need, } \\
\text { leaving a high concentration of a substance bilirubin }\end{array}$ & 20 & 35 & 45 & 1.75 \\
\hline 24 & $\begin{array}{l}\text { Jaundice occurs in new-borns because of a defect in liver enzymes or occurrence of gall } \\
\text { bladder blockage in the channels in which case the baby's skin color turns green olivine }\end{array}$ & 21 & 29 & 50 & 1.71 \\
\hline 25 & Jaundice may occur in the new-born due to contamination of the umbilical cord & 18 & 44 & 38 & 1.80 \\
\hline 26 & Jaundice analysis (ALP, AST ALT, GGT, PT...) & 22 & 44 & 34 & 1.88 \\
\hline 27 & $\begin{array}{l}\text { The patient is advised jaundice Elly eating sweets lean and eat more fruits and vegetables } \\
\text { and stay away from eating frozen }\end{array}$ & 44 & 18 & 38 & 2.06 \\
\hline 28 & $\begin{array}{l}\text { One of the changes in lifestyle may help prevent jaundice (such as maintaining a healthy } \\
\text { weight categorize) }\end{array}$ & 23 & 37 & 40 & 1.83 \\
\hline 29 & $\begin{array}{l}\text { It advised not to exposure to substances known to necrosis of the liver (such as phenol } \\
\text { and fourth carbon chloride) that causes liver cancer }\end{array}$ & 18 & 46 & 36 & 1.85 \\
\hline \multirow[t]{2}{*}{30} & $\begin{array}{l}\text { Treatment of jaundice depends on the security situation are causing H.hat advise proper } \\
\text { treatment after conducting tests to determine the type of jaundice }\end{array}$ & 18 & 44 & 38 & 1.80 \\
\hline & total & & & & 1.841 \\
\hline
\end{tabular}


Table.3 Association between nurse's knowledge and their gender

\begin{tabular}{|l|l|l|c|c|c|}
\hline Gender & & Know & Uncertain & Don't know & Total \\
\hline \multirow{2}{*}{ Male } & $\mathrm{F}$ & 710 & 403 & 193 & 1306 \\
\hline \multirow{2}{*}{ Female } & $\%$ & $54.37 \%$ & $30.86 \%$ & $14.77 \%$ & $100 \%$ \\
\hline \multirow{2}{*}{ Total } & $\mathrm{F}$ & 874 & 549 & 293 & 1716 \\
\cline { 2 - 7 } & $\%$ & $50.94 \%$ & $31.99 \%$ & $17.07 \%$ & $100 \%$ \\
\hline$X^{2}$ calculated $=$ & F & 1584 & 952 & 486 & 3022 \\
\cline { 2 - 7 } & $\%$ & $52.41 \%$ & $31.51 \%$ & $16.08 \%$ & $100 \%$ \\
\hline
\end{tabular}

Table.4 Association between nurse's knowledge and their age

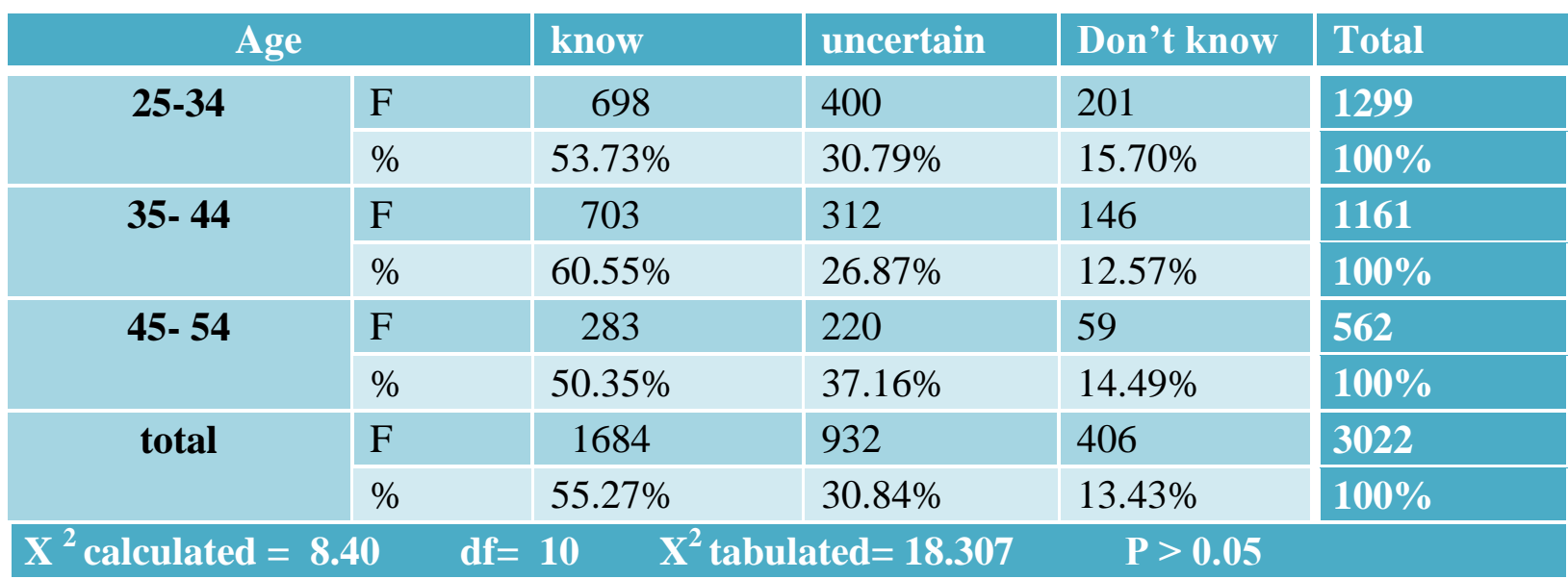

Table.5 Association between nurse's knowledge and their level of education

\begin{tabular}{|l|l|r|c|c|c|}
\hline Level of education & & know & uncertain & Don't know & Total \\
\hline Secondary nursing school & F & 627 & 490 & 208 & 1325 \\
\cline { 2 - 6 } & $\%$ & $47.34 \%$ & $36.98 \%$ & $15.68 \%$ & $100 \%$ \\
\hline Nursing institute graduate & F & 487 & 298 & 145 & 930 \\
\cline { 2 - 7 } & $\%$ & $52.36 \%$ & $32.05 \%$ & $15.59 \%$ & $100 \%$ \\
\hline \multirow{2}{*}{ College of nursing } & F & 521 & 168 & 78 & 767 \\
\hline \multirow{2}{*}{ Total } & $\%$ & $67.92 \%$ & $21.92 \%$ & $10.16 \%$ & $100 \%$ \\
\hline & F & 1635 & 956 & 431 & 3022 \\
\hline$X^{2}$ calculated $=22.72$ & $\%$ & $54.10 \%$ & $31.63 \%$ & $14.27 \%$ & $100 \%$ \\
\hline
\end{tabular}


Table.6 Association between nurse's knowledge and their years of experience

\begin{tabular}{|c|c|c|c|c|c|}
\hline \multicolumn{2}{|c|}{ Years of experience } & know & uncertain & Don't know & Total \\
\hline \multirow[t]{2}{*}{$1-9$} & $\mathbf{F}$ & 898 & 594 & 222 & 1714 \\
\hline & $\%$ & $52.39 \%$ & $34.66 \%$ & $12.95 \%$ & $100 \%$ \\
\hline \multirow[t]{2}{*}{ 10- 19} & $\mathbf{F}$ & 477 & 208 & 124 & 809 \\
\hline & $\%$ & $58.96 \%$ & $25.71 \%$ & $15.33 \%$ & $100 \%$ \\
\hline \multirow[t]{2}{*}{ 20- 29} & $\mathbf{F}$ & 397 & 77 & 25 & 499 \\
\hline & $\%$ & $79.55 \%$ & $15.43 \%$ & $5.02 \%$ & $100 \%$ \\
\hline \multirow[t]{2}{*}{ Total } & $\mathbf{F}$ & 1772 & 879 & 371 & 3022 \\
\hline & $\%$ & $58.63 \%$ & $29.08 \%$ & $12.27 \%$ & $100 \%$ \\
\hline & $=$ & $d f=$ & $X^{2} t a$ & ted $=12.592$ & $P>0.05$ \\
\hline
\end{tabular}

There is no significant relationship between age, gender \& years of employment and nurse's knowledge about.

There is a significant relationship between level of education, and nurse's knowledge.

\section{Recommendations}

Special training sessions should be designed and presented to these nurses.

A booklet should be designed and distributed to all nurse.

The study recommended developing assessment sheet for and daily nursing activities.

\section{References}

American Academy of Family Physicians. Jaundice in the Adult Patient Accessed 2/7/2014. pp. 115-18.

Bansal, V. and Schuchert, V.D. 2006 Jaundice in the Intensive Care Unit. Surgical of North America, 86.pp. 1495-1502.

Carol, R. and Taylor, RN, MSN, PhD. PriscillaLeMone, RN, DSN, FAAN. Sixth Edition. Fundamentals of Nursing. 2008. pp. 1186to 1190.
Click, R, Dahl-smuth, J, Fowler, L, D, Ubose, $\mathrm{J}$, Denean-Saxton, M, and Hebart, J (2013) An Osteopathic Approach to Reduction of Readmissions for Neonatal Jaundice Osteopathic Family Physician. pp. 5, 17.

Forrest, F.H. and Forrest, J.A.H. 2002 Causes of Obvious Jaundice in South West; Letter-postscript. Gut, pp. 609-616.

James, W. D., Elston, D. and Berger, T. G. (2005). Andrews's disease of the skin 10th ed. Philadelphia: W. B. Sanders.

Labori, K.J, Bjornbeth, B.A and Raeder, M.G (2003) Etiology and prognostic Implication of Server Jaundice in surgical Trauma Patients. Scandina Vian Journal of Gastroenterology, 38. pp. 102-108.

Labori, K.J. and Reader, M.G. 2004 Diagnosis Approach to Patients with Jaundice following Trauma. Scandinavain Journal of Surgery, 93.pp.176-183.

Lewis, S., Heitkemper, M., Dirksen, S. Medical- Surgical Nursing (assess and management of clinical problems). $5^{\text {th }}$ ed, 2000 by Mosby, Inc. pp. 11911192.

Marshall, C., Cook, D.J., Cristou, N.V., Bemard, G.R., Sprung, C.L. and Sibbald, W.J. 1995 Multiple Organ Dysfunction Score; A Reliabe 
Descriptor of a Complex Clinical Outcome. Critical Care Medicine, 23. pp. 1638-1652

Nadir S, Saleem F, Amin K, Mahmood K (2011). "Rational use of phototherapy in the treatment of physiologic jaundice neonatorum" (PDF). Journal of Pharmaceutical Sciences and Research (Journal of Pharmaceutical Sciences and Research) 3 (1). R-19

Smeltzer, C., Hinkle. L., Cheever. H. Text book of Medical- Surgical Nursing. 12ed 2010. Wolter Kluwer Health / lippincott Williams P. 1666.
Wheatey, M. and Heilpem, K.L. 2008 Jaundice; an Emergency Department Approach to Diagnosis and Management. Emergency Medicine Practice, 10, pp. 1-24.

Whitehead, M.W. Hiansworth, I. and Kingham, J.G.C. 2001 The Cause of Obvious Jaundice in South West Wales; perception versus Reality. Pp. 409.

Yu, Z., Zhan, J., Li, C. Q. and Zhou, H.M. 2012 Age and Gender Analysis of Jaundice patients. The Journal of Bioscience and Medicine, 2, 2. pp. 21216.

\section{How to cite this article:}

Abdulkareem Salman Khudhair. 2018. Assessment of Nurses Knowledge Regarding Jaundice in Basra Hospitals. Int.J.Curr.Microbiol.App.Sci. 7(09): 2248-2254.

doi: https://doi.org/10.20546/ijcmas.2018.709.278 